\title{
PARA UMA NOVA INTERPRETAÇÃO CONSTITUCIONAL EM MATÉRIA TRIBUTÁRIA
}

\author{
PAULO CALIENDO ${ }^{1}$
}

\begin{abstract}
RESUMO: O presente artigo tem por objetivo questionar os modelos usuais de interpretação constitucional em matéria tributário, propondo em alternativa um modelo de interpretação sistemática, que valorize os direitos fundamentais e os princípios constitucionais.

PALAVRAS-CHAVE: Direito Tributário; Direitos Fundamentais; Princípios Constitucionais; Interpretação Sistemática.
\end{abstract}

ABSTRACT: This article aims to change the common juridical interpretation's models on Constitucion in tax subjects for another interpretation based on fundamental rights and principles.

KEYWORDS: Tax Law; Fundamental Rights; Principles; Sistematic Interpretation on Constitucion.

SUMÁRIO: Introdução; 1. Da interpretação jurídica no pensamento conceitual, normativista e sistemático; 1.1. Quanto à exigência de coerência judicial; 1.2. Quanto ao alcance da exigência de coerência judicial; 1.3. Quanto à resposta judicial; 2. Da interpretação jurídico-tributária no pensamento conceitual, normativista e sistemático; 2.1. Pensamento Conceitualista: teoria do tributo e do fato gerador; 2.2. Pensamento Normativista: Norma Jurídico-Tributária (RegraMatriz de Incidência Tributária); 2.3. Pensamento Sistemático: valores jurídicos (concretização de direitos fundamentais); Conclusões Parciais; Bibliografia.

SUMMARY: Introduction; 1 . On legal interpretation under the conceptual, the normativist and the systematic thinking; 1.1. Concerning the demand for judicial coherence; 1.2. Concerning the reach of the demand for judicial coherence; 1.3. Concerning the judicial answer; 2 . On Taxation Law interpretation under the conceptual, the normativist and the systematic thinking; 2.1. Conceptualist thinking: Tax and taxable event theory. 2.2. Normativist thinking: Taxation Law norm (Matrix for tax incidence); 2.3. Systematic thinking: legal values (Realizing fundamental rights); Partial Conclusions; Bibliography.

\section{INTRODUÇÃO}

O Direito Tributário é talvez o ramo do conhecimento jurídico mais influenciado pelas consequências de uma boa interpretação constitucional,

Artigo recebido em 18.08.2010. Pareceres emitidos em 31.01.2011, 15.02.2011 e 25.05.2011.

Artigo aceito para publicação em 31.05.2011.

${ }^{1}$ Advogado. Doutor pela PUC/SP. Professor do Mestrado e Doutorado da PUCRS.

p.caliendo@terra.com.br 
talvez em virtude do fato de que o texto constitucional incorporou todo um conjunto de princípios e regras que o caracterizam com uma verdadeira Carta Repartição de Competências Tributárias e como uma Carta de Direitos Fundamentais do Contribuinte. Desse modo, estabelecer um modelo coerente de interpretação tributária é uma tarefa fundamental. A teoria da interpretação é diferente para cada modo de pensar o jurídico, produzindo diferenças claras nos seus resultados concretos e nas soluções práticas para os dilemas jurídicos. A interpretação tópico-sistemática é capaz de dotar o intérprete de uma gama vasta e sofisticada de instrumentos de análise, que lhe dão superioridade sobre os modelos anteriores.

O uso da interpretação sistemática, comum a outros ramos do Direito Público (Direito Constitucional, Administrativo, Ambiental, etc.) se constitui em uma novidade no Direito Tributário de tal modo que as mais correntes definições de Direito Tributário nos manuais nacionais se referem a este como o ramo que trata do estudo do tributo ou do poder soberano do Estado em tributar. Raras são as formulações que falam de um dever fundamental de pagar tributos ao invés de um mero poder político de cobrar impostos, bem como raras são as formulações que tratam de sua finalidade como sendo o financiamento dos Direitos Fundamentais em um Estado Democrático, quando no máximo se referem ao custeio do Estado. É em face dessas ausências injustificadas na doutrina tributária nacional que a tarefa de se propor uma interpretação sistemática e não positivista do tema seja tão incompreendida, ao ponto se ser julgada como incipiente, insegura ou superficial, visto que realmente se mostra como uma tarefa árdua e gigantesca de reconstruir todo o arcabouço jurídico-tributário (conceito de fato gerador, obrigação tributária, crédito tributário, etc.) sob uma nova formulação que agregue a noção de dever constitucional, direitos fundamentais do contribuinte e princípios constitucionais. Por óbvio, não é tarefa deste artigo esgotar o tema ou mesmo aprofundar desnecessariamente a matéria, visto que o seu objetivo é antes de mais nada proceder a uma provocação: é tempo de se propor uma nova interpretação constitucional em matéria tributária.

Esse novo modo de se compreender o Direito Tributário se insere no fenômeno do neoconstitucionalismo, ou seja, o novo modelo constitucional fundado na teoria dos direitos fundamentais. Dentre os diversos autores em destaque, podemos citar como precursores Robert Alexy $(1984)^{2}$ e Ronald Dworkin (1977) ${ }^{3}$ em suas obras seminais: "Teoria dos Direitos Fundamentais" (Theorie der Grundrechte) e "Levando os direitos a sério" (Taking rights seriously), respectivamente.

Dentre a vasta e significativa doutrina podemos citar as obras de: Herbert

${ }^{2}$ Cf. ALEXY, Robert. Teoria de los Derechos Fundamentales. Madrid: Centro de Estúdios Políticos y Constitucionales, 2001.

${ }^{3}$ Cf. DWORKIN, Ronald. Levando os direitos a sério. São Paulo: Martins Fontes, 2002. 
Hart (1961) ${ }^{4}$, Peter Haberle (1972) ${ }^{5}$, Laurence Tribe (1978) ${ }^{6}$, Gustavo Zagrebelsky (1992) ${ }^{7}$, Carlos Nino (1992) ${ }^{8}$, Castanheira Neves (1993) ${ }^{9}$, Luigi Ferrajoli $(1995)^{10}$ e Luis Prieto Sanchís $(1997)^{11}$, Miguel Carbonell (2003) entre outros, e na doutrina nacional, dentre outros, podemos citar Ingo Sarlet $(1998)^{13}$, Lênio Streck $(1999)^{14}$, Luís Roberto Barroso $(2003)^{15}$ e Écio Duarte $(2006)^{16}$

${ }^{4}$ A obra de Herbert Hart, especialmente "O Conceito de Direito" (The Concept of Law), tem sido citada como fonte da expressão do movimento denominado neoconstitucionalismo, por diferença de abordagem com a tradição positivista anterior. Apesar de ser considerado um autor positivista Hart irá adotar uma postura considerada inclusiva, visto que incorpora os problemas morais no interior da juridicidade e não os trata necessariamente como questões extrajurídicas (abordagem exclusiva). Para o autor, o Direito não possui um insulamento (isolamento) dos problemas morais da sociedade, de tal forma que há uma recusa do modelo dedutivo e a compreensão do Direito como uma prática social fundamentada na aceitação das regras e não apenas na sua imposição. Há uma aceitação do caráter teleológico e axiológico para a manutenção da coerência do sistema jurídico. Sobre o assunto ver o trabalho apresentado por BRASIL, Deilton Ribeiro. Positivismo inclusivo e Neoconstitucionalismo: as contribuições de Herbert L. A. Hart e de Santiago Sastre Ariza para a interpretação, aplicação e construção do direito. In: XVI Congresso Nacional do Conpedi, 2007, Belo Horizonte. Anais do XVI Congresso Nacional do Conpedi. Florianópolis: Fundação Boiteux, 2007. p. 6143-6161.

${ }^{5}$ Veja-se do autor as seguintes obras fundamentais HÄBERLE, Peter. Grundrechte im Leistungsstaat in: Veröffentlichungen der Vereinigung Deutscher Staatsrechtslehrer (VVDStRL) vol. 30, 1972 e HÄBERLE, Peter. Die offene Gesellschaft der Verfassungsinterpreten. In: Juristenzeitung (JZ) 1975. ${ }^{6}$ Cf. TRIBE, Laurence. American Constitutional Law. 1978.

7 Cf. ZAGREBELSKY, Gustavo. II diritto mite. Legge, diritti, giustizia. Torino: Einaudi, 1992 e ZAGREBELSKY, Gustavo. El derecho dúctil. Ley, derechos, justicia. Madrid: Trotta, 2003.

${ }^{8}$ Cf. NINO, Carlos. Ética y Derechos Humanos. Un ensayo de fundamentación. Buenos Aires: Astrea; 1984. Idem. La Constitución de la democracia deliberativa. Barcelona: Gedisa, 2003. Igualmente El constructivismo ético (1989) e Fundamentos de derecho constitucional (1992).

${ }^{9}$ Cf. NEVES, Castanheira. Metodologia jurídica. Problemas fundamentais. Coimbra: Coimbra Editora, 1993.

${ }^{10}$ Cf. FERRAJOLI, Luigi. Derechos y garantías. La ley del más débil. Madrid: Trotta, 2004. Idem. Direito e razão. Teoria do garantismo penal. São Paulo: RT, 2002. Veja-se ainda FERRAJOLI, L. El fundamento de los derechos fundamentales. Madrid: Trotta, 2005. Publicou ainda artigo na obra PISARELLO, Gerardo y DE CABO, Antonio (Eds.). La renta básica como nuevo derecho ciudadano. Madrid: Trotta, 2006.

${ }^{11}$ Cf. PRIETO SANCHÍS, Luis. Justicia Constitucional y Derechos Fundamentales. Madrid: Trotta, 2003; bem como a obra PRIETO SANCHÍS, Luis. Constitucionalismo y positivismo. México/DF: Fontamara, 1997.

12 Cf. CARBONELL, Miguel. Teoría del neoconstitucionalismo. Ensayos escogidos. Madrid: Trotta, 2003

${ }^{13}$ Cf. SARLET, I. W. A Eficácia dos Direitos Fundamentais. 1. ed. Porto Alegre: Livraria do Advogado, 1998.

${ }^{14}$ Cf. STRECK, L. L. Hermenêutica Jurídica e(m) crise. Uma exploração hermenêutica da construção do Direito. 3. ed. Porto Alegre: Livraria do Advogado, 2001. v. 1 e STRECK, L. L. Jurisdição Constitucional e Hermenêutica: Uma Nova Crítica do Direito. 1. ed. Porto Alegre: Livraria do Advogado, 2002. v. 1.

${ }^{15}$ Cf. BARROSO, L. R. Interpretação e aplicação da Constituição: fundamentos de uma dogmática constitucional transformadora. 5. ed. São Paulo: Saraiva, 2003.

${ }^{16}$ Cf. DUARTE, Écio Oto Ramos et POZZOLO, Susanna. Neoconstitucionalismo e Positivismo Jurídico: as faces da teoria do direito em tempos de interpretação moral da constituição. São Paulo: Landy, 2006. 
O neoconstitucionalismo possui como fundamento histórico o fenômeno de reconstitucionalização, principalmente dos países europeus (Itália, Alemanha. Espanha e Portugal). Este movimento democrático redefiniu o papel da Constituição e do próprio desenho do Estado Democrático de Direito.

Luis Roberto Barroso apresenta como principais referências deste modelo a Lei Fundamental de Bonn (1949), a criação do Tribunal Constitucional Federal (1951); a Constituição da Itália (1947), a Corte Constitucional da Itália (1956); a reconstitucionalização de Portugal (1976) e da Espanha (1978) ${ }^{17}$.

No Brasil o neoconstitucionalismo se firma com a reconstitucionalização do país com a promulgação da Constituição de 1988. O novo texto constitucional inaugurou uma nova fase do Estado brasileiro, superando décadas de autoritarismo. O neoconstitucionalismo irá apresentar como fundamentos filosóficos a superação do modelo positivista baseado em regras, por um modelo edificado sobre um sistema de direitos fundamentais estruturado sobre o conceito de dignidade da pessoa humana.

Segundo Barroso, o neoconstitucionalismo possui três grandes pilares teóricos: a) o reconhecimento de força normativa à Constituição; b) a expansão da jurisdição constitucional e c) o desenvolvimento de uma nova dogmática da interpretação constitucional ${ }^{18}$.

O reconhecimento de força normativa à Constituição alterou a percepção sobre o sentido e o significado do texto constitucional. Inicialmente a Constituição era vista tão somente como uma carta política de estruturação dos poderes do Estado e passou a ser vista no novo modelo como uma norma jurídica estruturante de todos os momentos da vida cidadã ${ }^{19}$. A ideia da supremacia da Constituição implica na solução do paradoxo de normas "protegidas" ou "imodificáveis" no âmbito da democracia, visto que o princípio democrático impõe a supremacia do interesse da maioria atual sobre decisões pretéritas. Há uma tensão entre as vontades dos antigos e as "verdades reveladas" pelos fundadores da Constituição (founding fathers) e os novos desafios sociais.

\footnotetext{
17 São obras do autor de referência sobre o assunto: BARROSO, Luís Roberto. Influência da reconstitucionalização de Portugal sobre a experiência constitucional brasileira. Themis - Revista da Faculdade de Direito da Universidade Nova de Lisboa, Edição Especial, p. 71, 2006.

O começo da história. A nova interpretação constitucional e o papel dos princípios no direito brasileiro, In: Temas de direito constitucional, t. III, 2005.___. Fundamentos teóricos e filosóficos do novo direito constitucional brasileiro (pós-modernidade, teoria crítica e pós-positivismo), In: Temas de direito constitucional, t. II, 2003; Revista de Direito Administrativo, 225/5, julho a setembro de 2001; Revista da EMERJ, 15/11, 2001; Interesse Público, 11/42, 2001; Revista da AJUFE, 67/51, julho a setembro de 2001; Revista Trimestral de Direito Público, n 29, 2002 . . A nova interpretação constitucional: ponderação, direitos fundamentais e relações privadas. Editora Renovar, 2003.

${ }^{18}$ Cf. BARROSO, Luís Roberto. Neoconstitucionalismo e constitucionalização do Direito. O triunfo tardio do Direito Constitucional no Brasil. Jus Navigandi, Teresina, ano 9, n. 851, 1 nov. 2005. Disponível em: <http://jus2.uol.com.br/doutrina/texto.asp?id=7547>. Acesso em: 03 out. 2008.

${ }^{19}$ Konrad Hesse foi um dos primeiros constitucionalistas a ressaltar a força normativa do texto constitucional expressa na vontade da constituição (Wille zur Verfasssung), em sua obra "A força normativa da Constituição" (Die normative Kraft der Verfassung - 1959).
} 
A expansão da jurisdição constitucional se caracteriza por um movimento de superação do entendimento da lei como expressão da vontade geral (França) ou de soberania do parlamento (Inglaterra), por uma concepção de supremacia da Constituição e dos direitos fundamentais, com a noção de sua imunidade perante o legislador infraconstitucional. O fenômeno de criação de Cortes Constitucionais se espalhou pelo continente europeu e depois pelo mundo, tendo como momentos marcantes: Alemanha (1951), Itália (1956), Chipre (1960), Turquia (1961), Grécia (1975), Espanha (1978), Portugal (1982), Bélgica (1984), Polônia (1986), Argélia (1989), Hungria (1990), Rússia (1991), República Tcheca (1992), Romênia (1992), República Eslovaca (1992) e Eslovênia (1993), África do Sul (1996), Moçambique (2003). Somente o Reino Unido, a Holanda e Luxemburgo mantiveram o modelo anterior de supremacia parlamentar, sem a possibilidade de controle constitucional por uma corte especializada. No Brasil, apesar de já existirem modelos anteriores $\left(E C n^{\circ} 16\right.$, de 1965), é somente com a nova Constituição de 1988 que irá se firmar uma verdadeira ampliação do direito de propositura, bem como a regulamentação das normas sobre as ações diretas de inconstitucionalidade.

A tensão entre a democracia e a Constituição e a harmonia entre os poderes legislativo, judiciário e executivo foram motivo de muitos estudos e, particularmente, a experiência constitucional norte-americana foi a que mais avançou no estabelecimento de medidas de equilíbrio institucional por meio da aplicação de freios e contrapesos para garantir técnicas de "auto-restrição na atividade de revisão da legislação" (judicial self-restraint) ${ }^{20}$. Desse modo, o controle da atividade legislativa pelo Judiciário passa a ser entendido apenas como sendo uma exceção. Dentre as técnicas utilizadas podemos citar $^{21}$ : i) cases and controversies; ii) standing to sue; iii) precedent; iv) comity; v) political questions ${ }^{22}$.

Estas permite o desenvolvimento de uma nova dogmática da interpretação constitucional pela superação da interpretação tradicional das normas jurídicas e pela incorporação radical de novos elementos teóricos sobre a resolução de conflitos normativos (tese da supremacia da Constituição, da presunção de constitucionalidade dos atos normativos do Poder Público, da interpretação

\footnotetext{
${ }^{20}$ Cf. SANTOS, Gustavo Ferreira. Neoconstitucionalismo e democracia. Brasília a. 43 n. 172 out./dez. 2006, p. 46.

${ }^{21}$ Cf. SOUSA, João Ramos de. Self-Restraint. Sub judice: justiça e sociedade, Lisboa, n. 12, jan./jun. 1998.

${ }^{22}$ Estas técnicas apresentam, segundo Gustavo Ferreira Santos, as seguintes características: cases and controversies entende que a controvérsia deve ser delimitada apropriadamente, de modo a permitir uma decisão precisa e não uma mera opinão. A standing to sue requer a exigência de que a parte prove o interesse direto na solução do caso. A regra do precedent vincula das decisões atuais às decisões anteriores, limitando os casos de reapreciação às razões suficientes para tanto. A regra do comity harmoniza o modelo judical em âmbito federativo, ao exigir a exaustão dos recursos aos tribunais estaduais, como condição de recurso às cortes superiores. A regra das political questions pretende afastar os julgamentos de casos eminentemente políticos, limitando as decisões às questões jurídicas stricto sensu. Ver, nesse sentido, SANTOS, Gustavo Ferreira. Neoconstitucionalismo e democracia. Brasília a. 43 n. 172 out./dez. 2006, p. 50.
} 
conforme a Constituição, o da unidade, coerência, da razoabilidade e o da efetividade). Dentre as novas categorias inseridas na interpretação podemos citar: as cláusulas gerais, os princípios, as colisões de normas constitucionais, a ponderação e a argumentação.

O neoconstitucionalismo foi assentado, segundo Barroso, em três pilares: i) histórico, na reconstitucionalização da metade final do século XX; ii) filosófico, na afirmação do pós-positivismo e na reaproximação entre Direito e ética; e iii) teórico, com a afirmação da força normativa da Constituição, da expansão da jurisdição constitucional e do desenvolvimento de uma nova dogmática da interpretação constitucional.

O neoconsitucionalismo, antes de se configurar em uma escola, é um movimento representado por posturas teóricas diversas, que possuem as seguintes características, segundo André Rufino do Vale ${ }^{23}$ : a) o papel de destaque conferido aos princípios e valores como componentes elementos estruturantes dos sistemas constitucionais; b) a importância da ponderação como método de interpretação, aplicação e resolução dos conflitos entre valores constitucionais; c) a aceitação de determinada conexão entre Direito e moral.

Prieto Sanchís sintetizou o neoconstitucionalismo da seguinte forma: "mais princípios que regras; mais ponderação que subsunção; mais Constituição que lei; mais juiz que legislador"24. Trata-se de um movimento de superação do clássico dualismo entre jusnaturalismo e positivismo, em que assumem um papel de destaque as normas de direitos fundamentais, dado que elas podem ser caracterizadas como fusão dos valores morais históricos de uma comunidade $^{25}$. É a riqueza da complexidade da compreensão dos direitos fundamentais que impôs uma nova revisão da tensa relação entre positivismo, realismo e jusnaturalismo. Vejamos, pois, o sentido e o alcance das normas de direitos fundamentais.

A concepção sistemática parte do postulado de que o Direito é composto por um conjunto de normas fundamentadas sobre valores, ou seja, o ordenamento jurídico tem em sua essência a preocupação com a realização de determinados "estados de coisas" (fins). O direito em suas prescrições emanará não somente comandos normativos, mas proposições estruturadas com fulcro em valores afirmados socialmente no texto constitucional. Desse modo, a concepção sistemática terá um caráter deontológico orientado por valores e não apenas axiológico, visto que o sistema jurídico não pode ser composto meramente por uma afirmação de valores, mas deve prever como estes valores constitucionalizados irão se concretizar por meio de comandos normativos.

\footnotetext{
${ }^{23}$ Cf. VALE, André Rufino do. Aspectos do Neoconstitucionalismo. Revista Brasileira de Direito Constitucional - RBDC n. 09 - jan./jun. 2007, p. 67.

${ }^{24}$ Cf. PRIETO SANCHÍS, Luis. Sobre el neoconstitucionalismo y sus implicaciones. In: Justicia Constitucional y Derechos Fundamentales. Madrid: Trotta, 2003, p. 101. Idem. Ley, principios, derechos. Madrid: Dykinson, 1998, p. 35.

${ }^{25}$ Cf. VALE, André Rufino do. Aspectos do Neoconstitucionalismo. Revista Brasileira de Direito Constitucional - RBDC n. 09 - jan./jun. 2007, p. 70.
} 


\section{DA INTERPRETAÇÃO JURÍDICA NO PENSAMENTO CONCEITUAL, NORMATIVISTA E SISTEMÁTICO}

O problema da interpretação jurídica aparece igualmente de modo diverso em cada modo de pensar o jurídico. Assim, podemos diferenciar os seguintes modos de interpretação:

\subsection{Quanto à exigência de coerência judicial.}

i) Pensamento Conceitualista:

Adota um modelo silogístico de interpretação, dominado pelo formalismo jurídico e pela concepção de que a tarefa interpretativa se caracteriza como sendo uma tarefa lógico-dedutiva. O modelo de solução decorre da compreensão fechada do sistema e de um tipo de coerência material rígida do raciocínio jurídico, de tal forma que não existem lacunas ou casos difíceis no Direito. O próprio sistema jurídico contém todas as respostas aos problemas do sistema, de tal modo que um problema sem solução dedutível não pode ser considerado um problema jurídico. Neste caso o juiz está submetido ao conjunto de axiomas e conceitos gerais da ciência do Direito.

Trata-se de um modelo de coerência judicial necessária ("necessary"), no sentido que as decisões judiciais estão inseridas no quadro geral de um sistema fechado e de coerência material rígida e, portanto, a coerência das decisões judiciais é absolutamente necessária com o sentido material do sistema de conceitos jurídicos. Segundo tal entendimento deve existir uma necessária vinculação judicial ao acervo jurídico vigente ("pre-existing law") e sobre o processo de evolução legal ou normativa.

ii) Pensamento Normativista:

Trata-se de um modelo de discricionariedade judicial em que ao juiz é autorizado preencher de sentido a norma jurídica, nos limites de sua moldura normativa. Assim, permite-se ao juiz solucionar o caso concreto com as suas preferências pessoais de natureza ética, política ou ideológica, desde que tais escolhas estejam inseridas no interior da moldura normativa. Os casos difíceis são sempre solucionados pelos juízes com base na discricionariedade judicial.

Para este entendimento a exigência de uma coerência judicial com o sistema jurídico somente é necessária do ponto de vista formal e desejável no seu sentido material, mas nada impede que o sistema produza posições contraditórias materialmente, porém legítimas pelo resultado da ação de competências tributárias diversas. Assim, trata-se de uma coerência desejável ("desirable"), ou seja, um dos requisitos que deverá ser tomado em conta, mas que poderá ser afastado por valores diversos na aplicação judicial.

iii) Pensamento Sistemático:

Trata-se de um modelo que exibe os requisitos de coerência necessária e suficiente ("sufficient"), ou seja, um requisito essencial na interpretação e aplicação do Direito. Segundo Dworkin ${ }^{26}$, o Direito deve ser entendido como

${ }^{26}$ DWORKIN, Ronald. Law's Empire. The Belknap Press of Havard University Press, 1986. 
uma voz organizada e coerente ('community of principle'); ou seja, uma comunidade de membros que entende estar governada por princípios comuns ("common principles"), isto é, capaz de apresentar uma justificação normativa geral. Existem casos difíceis e estes devem ser resolvidos conforme o sistema jurídico, mas respeitando as possibilidades de solução que emergem das conexões valorativas, decorrentes do caso concreto ${ }^{27}$.

\subsection{Quanto ao alcance da exigência de coerência judicial:}

Diversas são as noções sobre o alcance do conceito de coerência, dentre as quais podemos destacar:

i) alcance geral, em que deverão os juízes, ao julgar, procurar coerência com o sistema jurídico como um todo ${ }^{28}$. Este entendimento é utilizado pelo pensamento conceitualista, que determina um alcance geral e irrestrito da coerência que se espalha por todo o sistema, de raciocínio jurídico e judicial, exigindo um completo sistema lógico-dedutivo encadeado de conceitos. Por sua vez, o normativismo irá implicar tão somente em um modelo de coerência de alcance geral de sentido formal.

ii) tópica, no qual deverão procurar coerência com o sistema jurídico geral ou somente com uma parte deste.

\footnotetext{
${ }^{27}$ Misabel Derzi ao tratar da obra do Ministro Carlos Velloso refletiu sobre o dilema entre a justiça e os direitos fundamentais e a democracia, tendo por referência os estudos de Dworkin. Segundo a autora: "portanto, a questão da atuação da Suprema Corte nas democracias tem merecido a atenção dos mais interessantes filósofos e constitucionalistas. Se os juízes não são eleitos, como explicar que possam, criativamente, controlar a constitucionalidade das leis? Dworkin responde explicando que um regime político não será democrático porque a maioria do povo governa a si mesmo, mas se e na medida em que as decisões coletivas tratem o conjunto dos cidadãos com um respeito igual e com atenção igual. Ao interpretar os vagos e abstratos princípios constitucionais, a Corte limita a competência dos parlamentos, não em razão de uma superioridade inerente ao poder judicante, mas em nome da superioridade do poder do povo sobre os demais órgãos constituídos ou constitutivos de governo. A Corte está encarregada de fazer prevalecer a vontade profundo do povo (na Constituinte) contra a vontade episódica da maioria de seus representantes, que fazem as leis"; ver in DERzI, Misabel Abreu Machado. Construindo o Direito Tributário na Constituição. Belo Horizonte: Del Rey, 2004, p. ix.

${ }^{28}$ Cf. Julie Dickson: "(...) Dworkin (1977, and, although not yet written at the time of Levenbook's article, Dworkin 1986. "(...)Dworkin's account of integrity in adjudication requires judges to attempt to view the legal system as a whole as exhibiting coherence and speaking with one voice in interpreting the law, Dworkin does also recognise that compartmentalisation into different branches or areas of law is an indisputable feature of legal practice, and he accordingly attempts to integrate it within his vision of adjudicative integrity. He does so via his doctrine of local priority in interpretation, i.e. that if a given principle justifying a judicial decision does not fit at all well with the area of law which the case is classified as falling under, then this counts dramatically against deciding the case in accordance with that principle, no matter how well such an interpretation coheres with other areas of the law (see Dworkin 1986, ch. 7). However, because of the strong pull toward global coherence in law as integrity -- expressed in Dworkin's claim that it is necessary to strive to view the legal system as a whole as speaking with one voice, the voice of an authentic political community, in order that law can be seen as justifying state coercion (...)"; ver in DICKSON, Julie, "Interpretation and Coherence in Legal Reasoning", The Stanford Encyclopedia of Philosophy (Fall 2001 Edition), Edward N. Zalta (ed.), URL = <http://plato.stanford.edu/archives/fall2001/entries/legal-reas-interpret/>. Acesso em 12.09.04, às 21 horas.
}

DIREITOS FUNDAMENTAIS E J JUSTIÇA - ANO 5, N' 15, P. 230-257, ABR./JUn. 2011 
O pensamento sistemático irá permitir uma interpretação tópico-sistemática, organizando a possibilidade de soluções decorrentes de considerações e conexões valorativas, do caso concreto e à referência necessária com o sistema jurídico.

Um exemplo importante de interpretação sistemática pode ser encontrado no excelente estudo de Giovanni Sartor sobre o assunto, que abordou a dialética das disputas judiciais e do confronto entre teorias diversas e conflitantes por sua aceitação como interpretação oficial. Segundo este autor, uma disputa é um "intercâmbio dialético de teorias" ("dialectical exchange of theories"). Assim, o critério para determinar a "força comparativa de teorias competitivas" ("comparative strengh of competing theories") é a ideia de coerência. A parte que oferecer a teoria mais coerente irá possuir a maior força comparativa e, possivelmente, alcançar a vitória.

Segundo o autor, a ideia de coerência, nesse sentido limitado, pode ser entendida ${ }^{29}$ como:

a) compreensividade ("case-coverage"), ou seja, a capacidade de explicar um amplo campo de casos;

b) funcionalidade ("factor-coverage"), ou seja, a capacidade de levar em consideração argumentos e contra-argumentos consistentes. Dessa forma, a teoria mais consistente será aquela que referir a consideração do maior número de fatores explicativos, respondendo ao maior número de questionamentos contrários. Não há a defesa de uma única resposta possível, mas a da melhor resposta possível capaz de integrar diferentes visões valorativas na decisão judicial, permitindo a resolução leal de litígios axiológicos;

c) conectividade analógica ("analogical-connectivity"), na qual as premissas de uma teoria possibilitam a construção, por analogia, de outras premissas no interior do mesmo sistema proposicional;

d) sustentabilidade ("non-arbitrariness"), em que todas as premissas de uma teoria encontram-se suportadas mutuamente no interior do sistema proposicional, de tal forma que a solução permita a integração da solução do caso concreto em combinação com a preservação da integridade do sistema jurídico. Há, desse modo, uma possibilidade de interpretação tópico-sistemática.

A força evidente dessa abordagem é clara, visto que muitas vezes a disputa por interpretação oficial em matéria tributária envolve abordagens igualmente coerentes e conflitivas, nas quais qualquer uma das interpretações poderia surgir como aceitável para o caso. Dessa forma, a mera presunção de que o estudo do fenômeno jurídico-tributário é suficiente para se entender o raciocínio jurídico-tributário, deve ser afastada. Não há como se entender a própria evolução conceitual em Direito Tributário como mero fenômeno

29 Cf. SARTOR, Giovanni. Teleological arguments and theory-based arguments. Artificial Intelligence and Law. N. 10, Netherlands: Kluwer, p. 95-112, 2002, p. 103-104. 
subsuntivo ou dedutivo entre normas e conceitos, tornando-se necessária uma abordagem sistemática na qual a noção de coerência possui toda a sua força explicativa.

\subsection{Quanto à resposta judicial:}

Um caso interessante é decorrente do questionamento levantado por Dworkin da única resposta correta. Para o modelo estabelecido por Dworkin, o juiz sempre encontra a resposta correta no Direito e, portanto, o juiz não possui discricionariedade ou poder político. Os casos difíceis não representam escolhas jurídicas, mas aplicação de princípios jurídicos. Seguindo o problema apresentado por Dworkin, poderíamos apresentar o pensamento conceitualista como sendo aquele que defende a existência de uma única resposta correta do ponto de vista material, enquanto que o normativismo admite uma pluralidade de respostas materiais. O pensamento sistemático, por sua vez, poderia ser melhor descrito como sendo aquele em que poderá surgir a melhor resposta possível no sistema jurídico ${ }^{30}$.

\begin{tabular}{|c|c|c|c|}
\hline $\begin{array}{c}\text { TIPOS DE } \\
\text { PENSAMENTO }\end{array}$ & $\begin{array}{c}\text { PENSAMENTO } \\
\text { CONCEITUAL }\end{array}$ & $\begin{array}{c}\text { PENSAMENTO } \\
\text { NORMATIVISTA }\end{array}$ & $\begin{array}{c}\text { PENSAMENTO } \\
\text { SISTEMÁTICO }\end{array}$ \\
\hline coerência judicial & $\begin{array}{c}\text { necessário } \\
\text { ("necessary") }\end{array}$ & $\begin{array}{c}\text { desejável } \\
\text { ("desirable") }\end{array}$ & $\begin{array}{c}\text { suficiente } \\
\text { ("sufficient") }\end{array}$ \\
\hline $\begin{array}{c}\text { alcance da } \\
\text { coerência judicial }\end{array}$ & $\begin{array}{c}\text { alcance geral e } \\
\text { irrestrito }\end{array}$ & $\begin{array}{c}\text { alcance geral de } \\
\text { sentido formal }\end{array}$ & tópico-sistemática \\
\hline resposta judicial & $\begin{array}{c}\text { única resposta } \\
\text { correta do ponto } \\
\text { de vista material }\end{array}$ & $\begin{array}{c}\text { diversidade de } \\
\text { respostas } \\
\text { materiais }\end{array}$ & $\begin{array}{c}\text { melhor resposta } \\
\text { possível }\end{array}$ \\
\hline
\end{tabular}

\footnotetext{
${ }^{30}$ Apresentação feita por Albert Calsamiglia à edição espanhola da obra de Ronald Dworkin. Derechos en Serio. Barcelona, Editora Ariel, 1984. Segundo Casamiglia: "modelo de Dworkin evita vários problemas importantes: o primeiro, que o juiz não se constitua em legislador, o que significa que o poder judiciário tem como função garantir direitos preestabelecidos. Em segundo lugar, a tese de Dworkin é compatível com o postulado da separação de poderes, posto que o juiz está subordinado à lei e ao direito. O poder judiciário é "nulo" - como afirmava Montesquieu - porque sua função é garantir direitos. Em terceiro lugar: o modelo da resposta correta recusa a teoria do silogismo, mas aceita seu princípio político básico: o juiz não tem nem pode ter poder político. A função do juiz é garantir os direitos individuais e não assinalar objetivos sociais. $A$ função judicial é distinta da legislativa ou da executiva. Em quarto lugar: nos casos difíceis, os juízes não baseiam suas decisões em objetivos sociais ou diretrizes políticas. Os casos difíceis são resolvidos com base em princípios que fundamentam direitos. Sem dúvidas, todas estas teorias da função judicial podem ser criticadas. Entretanto, pode ser que a teoria de Dworkin da função judicial deva ser levada a sério porque não incorre nos exageros das teorias silogística e realista (que negavam os casos difíceis). Tampouco incorre nas contradições da teoria da discricionariedade judicial (pois de um modo ou outro conceder poder político ao juiz supõe trair o sistema de legitimação do estado democrático e também supõe a aceitação de leis retroativas)"; disponível em http://www.puc-rio.br/sobrepuc/depto/direito/pet_jur/patdwork.html. Acesso em 11.05.08, às 14 horas.
} 


\section{DA INTERPRETAÇÃO JURÍDICO-TRIBUTÁRIA NO PENSAMENTO CONCEITUAL, NORMATIVISTA E SISTEMÁTICO}

O problema da interpretação jurídica aparece igualmente de forma diversa em cada modo de pensar o Direito Tributário. O modo de interpretação tributária irá variar também em conformidade com o modelo teórico escolhido, de tal forma que os resultados e os métodos irão diferenciar-se de maneira significativa. Assim, podemos diferenciar os seguintes modos de interpretação jurídico-tributária:

2.1. Pensamento Conceitualista: teoria do tributo e do fato gerador.

O modelo conceitual irá distinguir hermenêutica e interpretação, enquanto graus de aplicação da atividade interpretativa. A hermenêutica trata de modo genérico sobre os modelos de apreensão de sentido, a interpretação propriamente dita se dirige à aplicação a determinado dispositivo legal. Assim, no entender de Carlos Maximiliano: "a hermenêutica é a teoria científica da arte de interpretar"31.

A hermenêutica tem por objeto a determinação do sentido e o alcance das expressões jurídicas, visto que o Direito é composto de termos gerais, normas dispersas, princípios e institutos diversos e é tarefa do intérprete aplicar ao caso concreto a norma jurídica. No pensamento conceitual a tarefa do intérprete é aquela que "extrai da norma tudo o que na mesma se contém" ${ }^{\prime 2}$. Assim entendia sabiamente a jurisprudência romana que "neque leges, neque senatusconsulta ita scribi possunt, ut omnes casus qui quandoque inciderit comprehendantur", ou seja, "nem as leis, nem o senatus-consultos podem ser escritos de tal maneira que em seu contexto fiquem compreendidos todos os casos em qualquer tempo ocorrentes", visto que as normas são previsões sobre programações intersubjetivas e intertemporais e, portanto, não é possível que abarquem todos os casos possíveis e imagináveis ${ }^{33}$. Desta forma, não é fácil a tarefa do intérprete que deve buscar encontrar na multiplicidade de normas, expressões e fatos no curso histórico a retomada da unidade do sistema jurídico, mediante uma aplicação científica.

$\mathrm{Na}$ definição de Carlos Maximiliano "interpretar é explicar, esclarecer; dar o significado de vocábulo, atitude ou gesto; reproduzir por ouras palavras um pensamento exteriorizado; mostrar o sentido verdadeiro de uma expressão; extrair, de frase, sentença ou norma, tudo o que na mesma se contém"34. A tarefa da interpretação não é somente tornar claro o sentido de determinada expressão ou norma, nem tampouco encontrar o sentido exato de determinada

${ }^{31}$ Cf. MAXIMILIANO, Carlos. Hermenêutica e aplicação do Direito. Rio de Janeiro: Forense, 2006, p. 01.

${ }^{32}$ Cf. M AXIMILIANO, Carlos. Hermenêutica e aplicação do Direito. Rio de Janeiro: Forense, 2006, p. 01.

${ }^{33}$ Cf. MAXIMILIANO, Carlos. Hermenêutica e aplicação do Direito. Rio de Janeiro: Forense, 2006, p. 01.

${ }^{34}$ Cf. MAXIMILIANO, Carlos. Hermenêutica e aplicação do Direito. Rio de Janeiro: Forense, 2006, p. 01. 
regra em relação com o conjunto das leis, mas encontrar o verdadeiro sentido intrínseco da expressão.

Conforme bem relata Paulo de Barros Carvalho a doutrina interpretativa convencional (conceitual) propõe a aplicação simultânea dos seguintes critérios $^{35}$ :

i) literal-gramatical: é aquele no qual o intérprete limita-se ao sentido literal da linguagem ordinária da norma e demanda, portanto, o conhecimento perfeito da linguagem e do idioma nacional. Este tipo de raciocínio tem sido questionado, visto que a palavra pode ter mais de um sentido, sentidos diversos em contextos variados ou ser objeto de ambiguidade, de tal modo que os hermeneutas têm preferido a aplicação de métodos mais completos de extração de sentido, ou seja, "mais importante e de mais força que a palavra é a intenção de quem a afirma" (prior atque potentior est, quam vox, mens dicenti ${ }^{36}$ );

ii) histórico: trata-se do critério que procurar a verificação de sentido por meio da investigação do contexto histórico em que foi editada a norma jurídica. O uso da investigação do contexto histórico não se compara, contudo, com a recuperação da vontade do legislador (mens legislatoris). A edição de uma nova lei faz parte de um processo complexo e irracional, marcado por intenções contraditórias, nas quais não se descobre de pronto o verdadeiro autor da norma jurídica, dado que a mesma proposição é resultado de retoques de todas as ordens ou de idiossincrasias de legisladores ou partidos políticos. Dessa forma, nem todas as informações decorrentes do contexto histórico (occasio legis) são relevantes, visto que o desenrolar histórico dissipa as antigas consistências de sentido do momento da sua edição ${ }^{37}$;

iii) lógico: é aquele que se utiliza das regras da lógica formal para a determinação do sentido da norma jurídica, dentre as quais se destacam: o princípio da identidade, da não contrariedade, do terceiro excluído, da razão suficiente e da finalidade ${ }^{38}$. O uso exclusivo da lógica e de um método matemático ou geométrico de interpretação é incapaz de encontrar a riqueza dos sentidos da linguagem e das normas jurídicas;

iv) teleológico: o sentido da norma é determinado pela verificação dos fins e objetivos do comando normativo, bem como encontrar a finalidade pretendida pela norma. Duas concepções têm disputado a primazia dos grandes objetivos da legislação tributária, a concepção in dúbio pro fiscum e a in dúbio pro contribuinte;

\footnotetext{
${ }^{35}$ Cf. CARVALHO, Paulo de Barros. Curso de Direito Tributário. São Paulo: Saraiva, 1999, p. 68-69. ${ }^{36}$ Cf. CELSO. Digesto, liv. 1, tít. 3. frag. 29 apud MAXIMILIANO, Carlos. Hermenêutica e aplicação do Direito. Rio de Janeiro: Forense, 2006, p. 101.

${ }^{37}$ Cf. MELO, José Eduardo Soares de. Interpretação e integração da norma tributária In Martins, Ives Gandra da Silva. Curso de Direito Tributário. São Paulo Saraiva, 2001, p. 138.

${ }^{38}$ Cf. COELHO, Luis Fernando. Lógica Jurídica e interpretação das leis. Rio de Janeiro: Forense, 1979, p. 76-77.
} 
v) sistemático: em que o sentido do comando normativo é pesquisado em conjunto com a multiplicidade das normas jurídicas. Segundo o Prof. Paulo de Barros Carvalho: "o método sistemático parte, desde logo, de uma visão grandiosa do direito e intenta compreender a lei como algo impregnado de toda a pujança que a ordem jurídica ostenta" ${ }^{\text {"39 }}$. Lembra Carlos Maximiliano que em Roma já se proibia que o juiz decidisse sem considerar o conjunto todo do ordenamento jurídico, por meio do brocardo: "é contra o Direito, julgar ou emitir parecer, tendo diante dos olhos, ao invés da lei em conjunto, só ou uma parte da mesma (incivile est, nisi tota lege perspecta, uma aliqua partícula ejus proposita, judicare, vel respondere $)^{40}$.

Muitos têm se questionado se a interpretação em matéria tributária deve seguir a mesma lógica e métodos gerais de interpretação ou se possui um modelo próprio. Para A.D. Giannini ${ }^{41}$ : "lo cierto es que las mismas reglas dominan la interpretación de cualquier norma, y ninguna de aquéllas autoriza a pensar que para el Derecho tributário deban seguirse critérios interpretatvios diversos de los que presiden la interpretación de cualquier ora clase de leys".

Assim, cada sistema jurídico-tributário irá permitir ou autorizar a utilização conjunta ou combinada dos critérios acima, de tal modo que se possa realizar a correta interpretação da norma tributária. No entender de Morselli, a interpretação e integração da norma tributária é uma atividade absolutamente essencial, em virtude do fato de que o Direito Tributário não se assenta sobre um único instituto, mas sobre um conjunto de institutos de naturezas diversas que são compreendidos em um sentido orgânico ${ }^{42}$. $\mathrm{O}$ objetivo da interpretação é, portanto, alcançar em cada caso a correta aplicação do conceito de tributo, por meio da aplicação de métodos de interpretação ${ }^{43}$.

Dessa forma, o intérprete é livre para utilizar os métodos mais importantes para alcançar o sentido e alcance da norma jurídica a ser aplicada, dentre eles não deve existir hierarquia, dado que o pluralismo metodológico deve respeitar

\footnotetext{
${ }^{39}$ Cf. CARVALHO, Paulo de Barros. Curso de Direito Tributário. São Paulo: Saraiva, 1999, p. 68-69. ${ }^{40}$ Cf. CELSO. Digesto, liv. 1, tít. 3. frag. 24 apud MAXIMILIANO, Carlos. Hermenêutica e aplicação do Direito. Rio de Janeiro: Forense, 2006, p. 105.

${ }^{41}$ Cf. GIANNINI, A.D. Instituciones de Derecho Tributario. Madri: Editorial de Derecho Financero, 1957, p. 32.

${ }^{42}$ Conforme Morselli: "Il dirito dellimposta non forma um solo ed único istituto, ma um insieme di istituti, in un certo senso orgânico. V'è certamente similarità, ad esempio, fra l'imposta sui terreni e l'imposta sui fabbricati, tant'è che per lungo tempo esse andarano confuse", ver in MORSELLI, Emanuele. Corso di Scienza della Finanza Pubblica. Padova: CEDAM, 1949, p. 141.

${ }^{43}$ Conforme Morselli: "Sicchè, dove in date norme singole, o insieme ordinate per formare um istiuto tributário, si vede mancante o non completamnte offero allinterprete quello che gli ocorre per risolver casi concreti, e però, quando cio che direttamente gli manca forma il principio di ragione di tal norma o istituto, allora egli revolge allá scienza per trarre da essa, com lógico critério, il principio lasciat intendere dal legislatore finanziario, quale egli medesimol'avrebbe voluto, secondo lê particolarità dei casi, se anche suo compito fosse stato quello di realizzare individualmente presso tutti il tributo ordinato", ver in MORSELLI, Emanuele. Corso di Scienza della Finanza Pubblica. Padova: CEDAM, 1949, p. 143.
} 
o pluralismo das situações de fato e de valores que podem reger determinado fenômeno jurídico ${ }^{44}$.

Conforme bem ensina Carlos Maximiliano, as regras gerais de hermenêutica se aplicam de modo idêntico às leis fiscais, com uma diferença fundamental de que a interpretação em matéria tributária conjuga-se à finalidade de realizar o poder de tributar, assim: "explicado o modo de entender a faculdade de distribuir pelo povo os encargos pecuniários do erário, cumpre fazer agora como se interpretamos textos em que o legislador usa daquela prerrogativa soberana" ${ }^{\prime 4}$, ou seja, para o autor a interpretação está radicalmente ligada ao exercício da soberania.

O pensamento conceitual irá desenvolver um raciocínio decorrente do encadeamento de conceitos, dentre os quais o de tributo será o mais importante. A exigência de um sistema com coerência interna é uma exigência da ciência jurídica e, particularmente do Direito Tributário, visto que, como foi reforçado por Sainz de Bujanda ao traduzir e prefaciar a famosa obra de A. D. Giannini Istitutzioni di Diritto Tributário, deve-se entender que:

"el orden no consiste tan sólo, ni primordialmente siqueira, em la circusntacia de que las nociones se encadenen unas a otras siguiendo exlusivamente la pauta marcada por la contextura de la matéria que se desarrolla. Lo importante es que esas ideas aparezcan debidamente jerarquizadas y que uma vez agrupadas atendiendo a su respectiva importancia y ala funcion que desempeñan en el sistema, el autor sepa mantererse fiel al orden preestablecida, haciendo que la exposición de las ideas primarias preceda a la de las ideas secundarias o complementarias",46.

Assim, entendia Carlos A Mersán, famoso tributarista paraguaio e um dos fundadores do ILADT (Instituto Latino-Americano de Direito Tributário) e que teve o privilégio da sua obra "Direito Tributário" ter sido traduzida por Dejalma de Campos, com Prefácio de Ives Gandra Martins e Apresentação de Geraldo Ataliba. Segundo o autor:

"Assim, esta disciplina tem seu estudo centrado no 'tributo' como o tem o Direito Penal no delito, como exemplifica o mesmo Jarach ou como o tem o Direito Trabalhista nas relações do capital com o Trabalho que, ao final de contas não constitui as relações especiais dos particulares, as quais independem do Direito Civil' ${ }^{\prime \prime 7}$.

\footnotetext{
${ }^{44}$ Cf. TÔRRES, Ricardo Lôbo. Normas de interpretação e integração do Direito Tributário. Rio de Janeiro: Forense, 1991, p. 83.

${ }^{45}$ Cf. MAXIMILIANO, Carlos. Hermenêutica e aplicação do Direito. Rio de Janeiro: Forense, 2006, p. 270.

${ }^{46}$ Cf. BUJANDA, Sainz de F. Estúdio Preliminar In GIANNINI, A.D. Instituciones de Derecho Tributario. Madri: Editorial de Derecho Financero, 1957, p. XVI.

${ }^{47}$ Cf. MERSÁN, Carlos. Direito Tributário.SP: RT, 1988, p. 05.
} 
A importância deste estudo é tão relevante para o Direito Tributário que este conceito se traduz num conceito genético desta disciplina, ou seja, ela funda e é o ponto de partida da própria autonomia didática do estudo do Direito Tributário. Conforme Carlos Mersán:

"Se esta é a matéria que doutrinariamente justifica o nascimento de um ramo autônomo, pode-se afirmar que ainda que exista outra justificativa maior na legislação positiva especializada que caracteriza aos Estados de qualquer sistema de governo - ditatorial ou democrático ${ }^{48}$ - referente aos impostos, as taxas e as contribuições e é por isso que Pugliese define a razão do estudo da nova disciplina como 'o próprio ordenamento jurídico tributário de um dado país"49.

A razão de tal entendimento, conforme decorre da compreensão de que um ramo do conhecimento somente se distingue dos demais quando apresenta institutos, categorias e regras próprios que Ihe garantam uma autonomia no quadro geral das ciências. Assim, a autonomia somente ocorre: i) quando possui princípios próprios e diferenciados dos demais; ii) quando as instituições que o formam possuem fundamentos comuns e iii) difere dos demais por suas características comuns. O autor irá repetir este entendimento da autonomia do Direito Tributário, fundado na noção de tributo como resultado deste poder de império do Estado em arrecadar tributos.

A homogeneidade do objeto de estudo do Direito Tributário, centrado na noção de tributo, é que irá garantir a sua emancipação como disciplina didaticamente autônoma de outros ramos do Direito. Revisados os principais entendimentos sobre a interpretação no pensamento conceitual, vejamos agora as inovações e peculiaridades do pensamento normativista.

2.2. Pensamento Normativista: Norma Jurídico-Tributária (Regra-Matriz de Incidência Tributária).

O pensamento normativista partirá de um modelo diverso de interpretação da norma jurídico-tributária, visto que para este o modelo de interpretação não visa apenas a extração de sentido do dispositivo normativo, mas especialmente a construção de sentido. Trata-se de um modo absolutamente revolucionário para a época em que foi formulado e para a formatação da ideia de Direito.

O uso pluralista de métodos de interpretação não resolve, contudo, o problema de se encontrar a correta extração de sentido do texto legal, visto que, como alegava Antônio Franco de Campos, em 1977, a utilização simultânea de métodos somente poderá gerar imperfeições, falhas e incoerências hermenêuticas, de tal modo que devemos encontrar um método superior de análise:

${ }^{48}$ Cf. CARVAlHO, A. A. Contreiras de. Doutrina e aplicação do Direito Tributário. São Paulo/ Rio de Janeiro: Freitas Bastos, p. 58.

${ }^{49}$ Cf. MERSÁN, Carlos. Direito Tributário. SP: RT, 1988, p. 05. 
"no geral, os métodos de interpretação estabelecidos pela doutrina, de per si considerado, não satisfazem plenamente, pois falhas, deficiências ou imperfeições ocorrem a cada passo, mesmo considerando o ecletismo de alguns. A solução dos problemas interpretativos pode ser encontrada na pesquisa da ratio, o que poderia levar-nos a abraçar o método teleológico, sem abandonarmos a natureza das coisas" ${ }^{50}$.

O positivismo irá encontrar este ponto de partida seguro para a interpretação jurídico-tributária no estudo da estrutura da norma jurídica. Assim afirmava Alfredo Augusto Becker, em sua obra de 1963, que:

"ao defrontar-se com a regra jurídica, o seu intérprete deve ter em mente, com extrema nitidez, a 'estrutura lógica' e a ' atuação dinâmica' de toda e qualquer regra jurídica. Isto posto, ele pode dividir a tarefa hermenêutica em quatro momentos:

Primeiro momento: dissecar a estrutura lógica daquela determinada regra jurídica a interpretar (...).

Segundo momento: Investigar e analisar os fatos jurídicos e nãojurídicos que constituem os problemas práticos a resolver (...).

Terceiro momento: diante da hipótese de incidência realizada, o intérprete conclui ter havido a incidência da regra jurídica porque esta é infalível (...).

Quarto momento: O intérprete observa se foram respeitados os efeitos jurídicos que resultaram da incidência da regra jurídica (...., ${ }^{, 51}$.

Como se pode notar, o pensamento de Alfredo Augusto Becker irá representar uma viragem hermenêutica na forma de interpretação jurídicotributária. Ele irá estabelecer uma forma de interpretação dinâmica da norma tributária e não apenas passiva ou exegética, que pretende extrair da norma um determinado sentido. O modelo de interpretação clássico era absolutamente passivo dentro de uma ordem conceitual fixa, formada por conceitos universais e axiomas fundamentais, diverso do modelo proposto por Becker que irá defender que:

"A lei tributária não é um falcão real que o punho do Executivo alça vôo para ir à caça do 'fato gerador'. A regra jurídica contida na lei (forma literal legislativa) é a resultante lógica de um complexo de ações e reações que se processam no sistema jurídico onde foi promulgada. A Lei age sobre as demais leis do sistema, estas, por sua vez, reagem; a resultante lógica é a verdadeira regra jurídica da lei que provocou o impacto inicial" ${ }^{\prime \prime 2}$.

\footnotetext{
${ }^{50}$ Cf. CAMPOS, Antônio J. Franco. Interpretação hermenêutica e exegese do direito tributário. São Paulo: Bushatsky, 1977. CAMPOS, Antônio J. Franco Direito Tributário. São Paulo: J. Bushatsky, 1975. ${ }^{51}$ Cf. BECKER, Alfredo Augusto. Teoria Geral do Direito Tributário. São Paulo: Saraiva, 1953, p. 102-103.

52 Cf. BECKER, Alfredo Augusto. Teoria Geral do Direito Tributário. São Paulo: Saraiva, 1953, p. 102-104.
} 
Irá o autor defender o cânone hermenêutico da totalidade do sistema jurídico como modo de compreensão do fenômeno jurídico, de tal forma que a interpretação será tarefa de conhecimento da totalidade da fenomenologia do sistema jurídico. Assim, uma lei ou artigo jamais será identificado com uma norma jurídica e talvez nem exista como tal, somente será possível extrair a regra jurídica da lei ou artigo em relação ao conjunto das demais leis vigentes (plano horizontal) e antecedentes (plano vertical).

A interpretação jurídica no positivismo passará a ter uma função teórico-sistemática menor do que no pensamento clássico. Irá assumir preponderância a Teoria Geral do Direito, enquanto Teoria da Incidência da Norma Jurídica, sendo que a principal função do intérprete será realizar um estudo pormenorizado da fenomenologia da incidência jurídica, de tal sorte a confirmar a ocorrência do fato gerador. Esta conclusão é tão forte no autor que ele irá denominar tal fenômeno de mitos e superstições na interpretação tributária e irá afirmar categoricamente que:

"O problema jurídico tributário que, no passado, mais apaixonou os estudiosos do Direito Tributário foi o da interpretação das leis tributárias. (...) O referido atavismo hermenêutico denuncia-se ainda muito forte (...) quando se trata de interpretar regras jurídicas que escolheram fatos jurídicos (atos jurídicos, negócios jurídicos, etc.) para a composição de suas respectivas hipóteses de incidência,"53.

Os anseios de Alfredo Augusto Becker ganharam os corações e as mentes dos mais brilhantes tributaristas nacionais da segunda metade do século XX. Dentre estes autores podemos destacar: Geraldo Ataliba, José Souto Maior Borges e Paulo de Barros Carvalho ${ }^{54}$. Esta conclusão será ainda mais explícita nos estudos de José Souto Maior Borges, que irá defender que somente uma teoria formal do Direito será capaz de constituir uma teoria geral do ordenamento jurídico e, portanto, definir a estrutura geral da totalidade do sistema jurídico.

Relevante é a explícita menção de José Souto Maior Borges à obra e ao paradigma de pensamento fundado por Becker, que assim se manifestou sobre a obra do tributarista gaúcho no Prefácio da obra Teoria Geral da Isenção Tributária, de 1969: "são por demais conhecidas as metáforas vez por outra encontradas em alguns autores para caracterizar o fenômeno da tributação: expressões como patologia tributária, manicômio jurídico-tributário e clínica fiscal atestam o estado de espírito que se encontra a doutrina".

O autor irá desenvolver uma das obras mais profundas sobre a aplicação do pensamento normativista (positivismo metodológico), aplicado ao Direito

${ }^{53}$ Cf. BECKER, Alfredo Augusto. Teoria Geral do Direito Tributário. São Paulo: Saraiva, 1953, p. 101-102.

${ }^{54}$ Cf. CARVALHO, P. B. . Homenagem a Alfredo Augusto Becker. In: Dejalma de Campos. (Org.). Tributo a Alfredo Augusto Becker. São Paulo: Academia Brasileira de Direito Tributário, 1995, v. p. -. 
Tributário, na sua obra Obrigação Tributária (Uma introdução metodológica), publicada em São Paulo, em 1984. De outro lado, o método formal possui um valor pragmático, visto que ele é capaz de resolver problemas concretos ao "(...) solucionar problemas de interpretação e aplicação do Direito" A tarefa do intérprete é submeter uma determinada hipótese teórica de uma dedução de uma norma à testabilidade, visto que as normas não podem ser verificadas, mas tão somente testadas perante o conjunto do sistema jurídico, de tal modo que o cânone da totalidade do sistema jurídico poderá provar a existência ou inexistência de uma norma jurídica determinada ${ }^{56}$.

Como exemplo, toma José Souto Maior Borges o caso do conceito de obrigação tributária, e afirma que na teoria clássica do Direito Tributário (para nós o conceitualismo), o termo "obrigação tributária" não é mero correspondente do grupo finito de particulares, mas denota a propriedade do universal existente em qualquer norma jurídica pensável. Esta visão essencialista, que procura entre a palavra e o objeto o correspondente conceito perfeito, é rechaçada pelo autor, que irá afirmar que "a tese da patrimonialidade da obrigação tributária é sustentada, na doutrina brasileira tradicional, em

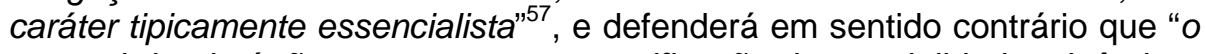
estar obrigado é tão-somente uma especificação das modalidades deônticas de regulação do comportamento humano"58. Dessa forma, o autor irá defender que não existem essencialidades ou essências a serem descritas por palavras sob a forma de conceitos, mas de construções normativas que regulam a conduta humana sob a forma de modalidades do dever-ser (deôntico): obrigatório, permitido e proibido.

A viragem radical do estudo da fenomenologia da incidência tributária irá ocorrer com os estudos revolucionários de Paulo de Barros Carvalho ${ }^{59}$. Este autor irá sofisticar radicalmente os estudos sobre a fenomenologia da incidência da norma tributária na sua obra seminal "Teoria da Norma Tributária", de 1973. Para esse autor, o grande problema do estudo do Direito Tributário está na conceituação dos fundamentos do Direito e na definição de um método adequado para o estudo do fenômeno tributário, sendo que muitos dos problemas de interpretação do Direito Tributário são problemas de definição dos elementos nucleares de entendimento do jurídico. Assim, será a partir do

\footnotetext{
${ }^{55}$ Cf. BORGES, José Souto Maior. Obrigação Tributária (Uma introdução metodológica). São Paulo: Saraiva, 1984, p. 20.

${ }^{56}$ Cf. BORGES, José Souto Maior. Obrigação Tributária (Uma introdução metodológica). São Paulo: Saraiva, 1984, p. 65.

${ }^{57}$ Cf. BORGES, José Souto Maior. Obrigação Tributária (Uma introdução metodológica). São Paulo: Saraiva, 1984, p. 108.

${ }^{58}$ Cf. BORGES, José Souto Maior. Obrigação Tributária (Uma introdução metodológica). São Paulo: Saraiva, 1984, p. 130.

${ }^{59}$ Cf. CARVALHO, P. B. . Sobre o percurso de construção de sentido: modelo de interpretação do direito tributário. In: André Ramos Tavares; Gilmar Ferreira Mendes; Ives Gandra da Silva Martins. (Org.). Lições de Direito Constitucional em Homenagem ao Jurista Celso Bastos. São Paulo: Saraiva, 2005, v. , p. 09-24.
} 
conceito "atômico" de norma jurídica que todo o conhecimento será estruturado, afinal o problema do direito será um problema da linguagem, ou melhor dizendo, de mal uso da linguagem.

Assim, é somente a partir de bases sólidas, inquestionáveis que poderá surgir uma verdadeira interpretação livre de apriorismos e concepções essencialistas, de tal modo que "surge, enfim, o esboço de um enfoque global do Direito Tributário, por desdobramento lógico de noções vestibulares da ciência jurídica"60.

A concepção normativista terá um entendimento de interpretação tributária centrada nas seguintes características ${ }^{61}$ :

i) construtivismo: o modelo de interpretação normativista acredita num papel criativo e dinâmico do intérprete, divergindo claramente da concepção de que a interpretação seja um modo de extração de sentido do texto, realizando uma passagem para o modelo de construção de sentido do texto, por meio do estudo da incidência da norma tributária;

ii) ausência de apriorismos: uma crítica fundamental do modo de pensar normativista está na negação da ausência de apriorismos interpretativos, tais como o célebre debate sobre a prevalência da interpretação pró-fisco (in dúbio pro fisco) ou pró-contribuinte (in dúbio contra fisco), como sendo posições superadas de um imperativismo do Direito, ou seja, de uma concepção que entendia que as normas jurídicas representavam uma visão correta de mundo ou eram uma representação perfeita da essência das relações sociais. Para Paulo de Barros Carvalho, "a visão imperativista ganhou dimensão com o jusnaturalismo, que no ímpeto de identificar o Direito com o justo, com um conjunto de princípios normativos, puramente ideais, de validez universal e permanente, chegaram por concluir que haveria um verdadeiro comando, no sentido de obediência a esses princípios, não sendo o Direito o comportamento humano que os violassem, ou melhor, os ilícitos"62. O entendimento do autor reforça a concepção de que a norma jurídica é uma construção humana, que deve no âmbito de seu contexto ser conhecida;

iii) ausência de autonomia interpretativa: a interpretação em matéria tributária não possui regras ou leis interpretativas diversas das demais áreas jurídicas, sendo que as mesmas regras que orientam a interpretação em todas as áreas do Direito também serão aplicáveis ao Direito Tributário. Nada impede, contudo, que existam particularidades de cada sistema tributário em específico;

iv) preocupação com a linguagem: o foco será revertido do estudo do ser

\footnotetext{
${ }^{60}$ Cf. CARVALHO, Paulo de Barros. Teoria da Norma Tributária. 2. ed.. SP: Revista dos Tribunais, 1981 , p. 18.

${ }^{61}$ Cf. CARVALHO, P. B. ; SOUSA, R. G.; CANTO, G. U. ; JARACH, D. ; ATALIBA, G. . Interpretação do Direito Tributário. São Paulo: Saraiva e EDUC, 1975.

${ }^{62}$ Cf. CARVALHO, Paulo de Barros. Teoria da Norma Tributária. 2. ed.. SP: Revista dos Tribunais, 1981, p. 31.
} 
e das realidades em si (teoria ontológica) e passará a preocupar-se com a auto-referência do discurso (teoria retórica) ${ }^{63}$ e, portanto, o estudo da linguagem jurídica será a preocupação primeira na interpretação jurídica. Não se trata, contudo, da interpretação literal ou gramatical do texto, mas da estrutura do sentido, de sua sintaxe, do que compõe a correta construção do discurso jurídico;

v) neutralidade valorativa: em razão da inexistência de elementos objetivos e universais capazes de determinar o que é o bom ou correto valorativamente, em face de um pluralismo axiológico na sociedade moderna. A norma jurídica, destituída de quaisquer pontos de referência material, representará o que existe de atemporal e universal na Teoria Geral do Direito;

vi) fechamento formal do sistema: a situação de confusão conceitual (carnaval tributário) gerou um profundo desconforto com a intrusão de conceitos extrajurídicos no entendimento do fenômeno tributário, como se qualquer abertura para informações e valores extrajurídicos se caracteriza-se como uma corrupção da pureza do sistema tributário. A aversão à submissão do Direito Tributário à ciência das Finanças, ao Direito Financeiro ou Econômico gerou, como reação, uma defesa do fechamento formal do sistema a contatos externos. Como resultado há uma negação unânime da validade de uma interpretação econômica do Direito Tributário, como uma das piores iniciativas que já ocorreram e um grave erro metodológico de usar instrumentais inadequados para conhecer o fenômeno tributário.

Estes elementos irão caracterizar a interpretação tributária sob a égide do pensamento normativista, representando um esforço sério e sofisticado de aperfeiçoamento institucional e teórico, que muito auxiliou o país e formou toda uma geração comprometida de juristas em nosso país, especialmente nos duros anos de reforço da autoridade fiscal, durante o regime militar.

Esta teoria será aperfeiçoada e levada a um novo patamar e paradigma de interpretação nos estudos revolucionários de Paulo de Barros Carvalho sobre o fenômeno de incidência da norma jurídica, com a obra Direito Tributário - Fundamentos Jurídicos da Incidência. (1998). Inacreditavelmente, o autor será o maior construtor de uma teoria completa sobre a estrutura da norma jurídica, com a Regra-Matriz de Incidência Tributária e, posteriormente, irá avançar para um novo patamar de análise sistêmica sobre o fenômeno jurídico-tributário. Esta nova fase demonstrará a radicalização de alguns pressupostos teóricos pré-existentes e a incorporação de novos postulados e instrumentos de análise.

O pensamento sistemático irá reunir um conjunto diverso de experiências e programas teóricos, no entorno do objetivo de repensar a Teoria Geral do Direito Tributário.

${ }^{63}$ Cf. Cf. CARVALHO, Paulo de Barros. Direito Tributário - Fundamentos Jurídicos da Incidência. São Paulo: Saraiva, 1998, p. 05. 
2.3. Pensamento Sistemático: valores jurídicos (concretização de direitos fundamentais).

O pensamento sistemático irá produzir um conjunto de novos modelos, instrumentos e agenda de trabalho, muito superior ao que existia nos momentos anteriores, implicando em uma nova forma de interpretação jurídico-tributária. Segundo Juarez Freitas: "numa interpretação tópico-sistemática consciente, o Direito passa a ser visto como um só, variando, embora, em grau, a intensidade dos princípios que regem os subsistemas, os quais devem ter harmonia com os princípios hierarquizados como fundamentais"s64.

O pensamento sistemático parte da impossibilidade da compreensão normativista da teoria da ciência jurídica como ciência normativa, visto que os enunciados deônticos não podem ser entendidos em sentido descritivo ${ }^{65}$. Segundo Guastini, a teoria normativista da ciência jurídica fundamenta-se em duas teses principais ${ }^{66}$ :

i) ambiguidade pragmática: os enunciados deônticos podem ser empregados para realizar atos de linguagem diferentes, ou seja, podem ser usados para descrever uma prescrição o para formular uma prescrição ou proibição;

ii) validade normativa: os enunciados deônticos são o único modo apropriado de descrever normas. Descrever uma norma no pensamento normativista significa "asseverar a validade de uma norma"67.

Como bem leciona Ricardo Guastini, não há como a ciência jurídica exprimir-se mediante enunciados deônticos, principalmente porque não há como se cogitar que estes descrevam o "verdadeiro" ou "único" significado das normas jurídicas. Não há, contudo, como compartilhar desse entendimento, dado que não há como se aceitar que exista apenas uma interpretação verdadeira. Assim "(...) um enunciado deôntico (positivo ou negativo) é empregado para formular uma norma, não para afirmar ou negar a sua validade" ${ }^{\mathrm{6}}$.

A interpretação sistemática exige uma compreensão coerente do sistema jurídico, dessa forma conforme Juarez Freitas: "cada preceito deve ser visto como parte viva do todo, porque apenas no exame de conjunto tende a ser melhor equacionado qualquer caso, quando se almeja uma bem-fundada hierarquização tópica dos princípios tidos como proeminentes" ${ }^{\prime 69}$.

A interpretação sistemática em Direito Tributário é, por outro lado, parte

\footnotetext{
${ }^{64}$ Cf. FREITAS, Juarez. A interpretação Sistemática do Direito. 3. ed. São Paulo: Malheiros, 2002, p. 288.

${ }^{65}$ Cf. GUASTINI, Ricardo. Das Fontes às Normas. São Paulo: Quartier Latin, 2005, p. 104.

${ }^{66}$ Cf. GUASTINI, Ricardo. Das Fontes às Normas. São Paulo: Quartier Latin, 2005, p. 90-91.

${ }^{67}$ Cf. GUASTINI, Ricardo. Das Fontes às Normas. São Paulo: Quartier Latin, 2005, p. 94.

${ }^{68}$ Cf. GUASTINI, Ricardo. Das Fontes às Normas. São Paulo: Quartier Latin, 2005, p. 98.

${ }^{69}$ Cf. FREITAS, Juarez. A Interpretação Sistemática do Direito. 3. ed. São Paulo: Malheiros, 2002, p. 70.
} 
da interpretação sistemática em Direito Constitucional, de tal modo, como leciona Luís Roberto Barroso:

"O direito objetivo não é um aglomerado aleatório de disposições legais, mas um organismo jurídico, um sistema de preceitos coordenados ou subordinados, que convivem harmonicamente. A interpretação sistemática é fruto da idéia de unidade do ordenamento jurídico. Através dela, o intérprete situa o dispositivo a ser interpretado dentro do contexto normativo geral e particular, estabelecendo as conexões internas que enlaçam as instituições e as normas jurídicas. Em bela passagem, registrou Capograssi que a interpretação não é senão a afirmação do todo, da unidade diante da particularidade e da fragmentaridade dos comandos singulares. No centro do sistema, irradiando-se por todo o ordenamento, encontra-se a Constituição, principal elemento de sua unidade, porque a ela se reconduzem todas as normas no âmbito do Estado. A Constituição, em si, em sua dimensão interna, constitui um sistema. Essa idéia de unidade interna da Lei Fundamental cunha um princípio específico, derivado da interpretação sistemática, que é o princípio da unidade da Constituição, para o qual se abre um capítulo específico mais adiante. A Constituição interpretase como um todo harmônico, onde nenhum dispositivo deve ser considerado isoladamente." ${ }^{70}$

A interpretação sistemática é um caso da interpretação constitucional e decorre da existência do Estado Democrático de Direito (Estado Constitucional), que por sua vez representa uma evolução institucional importante perante 0 Estado de Direito. A passagem do Estado de Direito para o Estado Constitucional constitui uma mudança de paradigmas ${ }^{71}$ :

i) no Estado de Direito prevalece o princípio da segurança jurídica e do consenso; enquanto que no Estado Constitucional ocorre a prevalência do equilíbrio entre o consenso e o conflito. O Estado Constitucional deve prever dois grandes princípios: a preservação do pluralismo de valores e seu confronto leal;

ii) o Estado de Direito tenta preservar um modelo de coesão social (noção de vida boa identificada com o burguês, pater famílias e comerciante); no Estado Constitucional não há conceito de vida boa, não existem modelos fechados de vida. Os direitos fundamentais é que constituem o substrato do ethos social;

iii) o Estado de Direito representa uma situação ideal (ficção) de indivíduos atomizados ou de uma estrutura social homogênea; o Estado Constitucional, por sua vez, representa o claro reconhecimento de uma base fática plural e conflituosa;

${ }^{70}$ Cf. BARROSO, Luís Roberto. Interpretação e Aplicação da Constituição. 6. ed., 2004, Saraiva, p. 136-137.

1 Sobre o tema veja-se Zagrebelsky, Gustavo. II diritto mite: legge, diritti, giustizia. Torino: Einaudi, 1992.

DiREITOS FundAMENTAIS $\varepsilon$ J JUSTIÇA - AN0 5, N 15, P. 230-257, ABR./Jun. 2011 
iv) o modelo hermenêutico típico no Estado de Direito é o raciocínio subsuntivo da regra (silogismo legal) do Direito, consagrado na Jurisprudência de conceitos; o modelo do Estado Constitucional é a concreção de valores, onde existe uma dogmática fluída, na aplicação de princípios e valores (Jurisprudência de valores);

v) no Estado de Direito apresenta-se uma homogeneidade do Estado legislativo, em que o ordenamento jurídico aparece como dado; por sua vez, no Estado Constitucional aparece a heterogeneidade do ordenamento jurídico como problema. Se no primeiro caso a lei é pacificadora de conflitos sociais; no segundo caso, a lei representa um compromisso entre valores pluralistas. Ela não é mais produto neutro (podendo representar grupos determinados). Os princípios correm o risco de se tornarem um recurso de esvaziamento semântico de soluções substanciais, pela inexistência de regras e compromissos. Fim da "beleza" lógica defendida pelos normativistas.

É com base nestes fundamentos que se sustenta a natureza valorativa da resolução de conflitos $^{72}$ no ordenamento jurídico constitucional ${ }^{73}$.

Uma interpretação sistemática objetiva antes de mais nada, na elaboração de uma nova dogmática, aberta e flexível, atenta aos desafios de nosso tempo. Essa nova dogmática se assume como teoria jurídica, no sentido expresso por Ricardo Guastini:

"Diremos então que a teoria jurídica articula-se, grosso modo, em dois setores de investigação distintos: por um lado, a análise lógica da linguagem legislativa (que inclui a análise estrutural do sistema jurídico); por outro, a análise lógica da linguagem dos juristas (mas também dos outros operadores do direito, especialmente dos juízes)",74.

\subsubsection{Da interpretação sistemática no Direito Tributário.}

Considerando que o sistema jurídico é um todo ordenado de princípios, regras e valores, cabe destacar o papel de relevo desempenhado pelos princípios em uma teoria sistemática do Direito Tributário. Dentre os diversos aspectos podemos destacar que:

- as normas de comportamento, tais como as regras, teriam os seus fundamentos normativos derivados direta ou indiretamente dos princípios;

- os princípios possuem uma prevalência sistêmica em relação às regras em função de sua relevância;

\footnotetext{
72 Sobre o assunto veja-se STEINMETZ, Wilson Antônio. Colisão de Direitos Fundamentais e Princípio da Proporcionalidade. Porto Alegre: Livraria do Advogado, 2001.

${ }_{73}$ Para uma completa verificação da proteção dos Direitos Fundamentais veja-se a obra de SARLET, Ingo Wolfgang. A eficácia dos direitos fundamentais. Porto Alegre: Livraria do Advogado, 2006.

${ }^{74}$ Cf. GUASTINI, Ricardo. Das fontes às normas. São Paulo: Quartier Latin, 2005, p. 382.
} 
- os princípios possuem um conteúdo axiológico claro e, portanto, seriam detentores dos valores normativos de um sistema jurídico;

- os princípios são detentores de "forma jurídica e conteúdo moral"75. Eles teriam o sentido de racionalidade prática, desta forma eles representariam uma forma de superação da tese positivista da separação entre o direito e a moral.

\subsubsection{Da interpretação tópico-sistemática.}

A interpretação tópico-sistemática, defendida especialmente por Juarez Freitas, caracteriza-se por hierarquizar prudencialmente princípios, regras e valores, realizando um redimensionamento do problema das antinomias entre princípios e regras, de tal modo que os princípios ocupam o papel de cúpula do sistema. Desse modo, esta forma de interpretação irá igualmente ressaltar a importância da solução adequada ao caso concreto ${ }^{76}$.

Desse modo, as regras apresentam uma densificação de princípios (normas de fundamento) e carregam valores. Assim, se houver o conflito entre uma norma de conduta descrita (regra) e uma norma que fundamenta condutas necessárias (princípios), o conflito irá ser deslocado para o fundamento (princípio) da regra sobre uma conduta e a norma de fundamento de condutas necessárias (princípio). Se esses fundamentos ou princípios ainda estiverem no mesmo nível ou não se possa solucionar o seu conflito, então caberá ao intérprete verificar os fundamentos dos fundamentos, ou seja, os valores normativos que o ordenamento jurídico tenta proteger por meio de normas jurídicas. Assim, caberá ao intérprete proceder a escolhas axiológicas com base no sistema constitucional ${ }^{77}$.

\footnotetext{
${ }_{75}^{75}$ Cf. VIGO, Rodolfo Luis. A interpretação jurídica. São Paulo: RT, 2005, p. 152.

${ }^{76}$ Cabe ressaltar o comentário Helenilson Cunha Pontes ao "Princípio da Não-Cumulatividade no voto proferido pelo Ministro Carlos Velloso no Recurso Extraordinário n. 170.412-8-SP", em que defendeu que: "o sistema normativo é o resultado da articulação entre princípios e regras, onde os princípios ocupam o vértice da pirâmide, estruturando e iluminando todo o sistema e cujo movimento não se dá somente de cima para baixo, mas nos dois sentidos, em que uma norma completa e dá significado a outra. Por isso que o melhor modo de compreender princípios e regras é diferenciado-os por graus de concretude, cuja intensidade também poderá variar de acordo com o caso concreto"; ver in PONTES, Helenilson Cunha. Princípio da Não-Cumulatividade no voto proferido pelo Ministro Carlos Velloso no Recurso Extraordinário $n^{\circ}$ 170.412-8-SP in DERzI, Misabel Abreu Machado. Construindo o Direito Tributário na Constituição. Belo Horizonte: Del Rey, 2004, p. 27.

${ }^{77}$ Leciona Juarez Freitas com propriedade que: "Mais: a antinomia entre as regras oculta, necessariamente, uma antinomia ente princípios. Estes ostentam validade formal e não são mais deveis do que aquelas. A diferença reside em que as regras apresentam função hermenêutica instrumental, isto é, devem servir à realização dos princípios. Aliás, a tarefa da hierarquização, no uso dos silogismos dialéticos, culmina justamente na positivação do princípio como superior"; ver in FREITAS, Juarez. A melhor interpretação constitucional "versus" a única resposta correta. In: AFONSO DA SILVA, Virgílio (Org.) Interpretação Constitucional. São Paulo: Malheiros, 2005, p. 318.
}

Direitos FundamentaIS E E JUSTIÇA - ANo 5, N' 15, P. 230-257, AbR./Jun. 2011 
Para ilustrar, na decisão o intérprete irá proceder da seguinte forma:

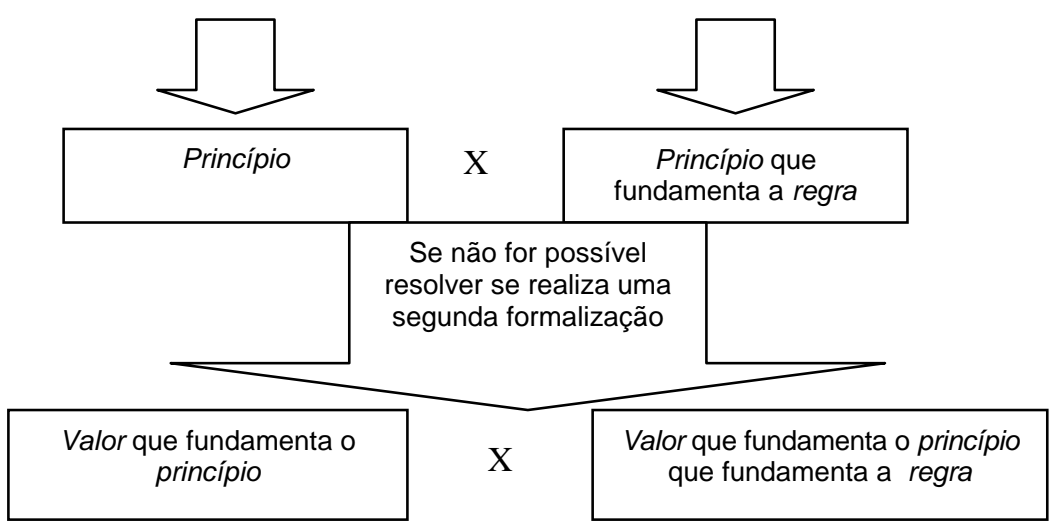

Para ilustrar os modos de solução do presente caso, veja-se o quadro abaixo:

\begin{tabular}{|c|c|c|}
\hline & $\begin{array}{c}\text { INTERPRETAÇÃO } \\
\text { NORMATIVISTA } \\
\text { (LEGALISTA) }\end{array}$ & $\begin{array}{l}\text { INTERPRETAÇÃO } \\
\text { TÓPICO-SISTEMÁTICA }\end{array}$ \\
\hline $\begin{array}{l}\text { EXEMPLO } \\
\text { JURISPRUDENCIAL }\end{array}$ & $\begin{array}{l}\text { “(...) Pela letra da lei, há } \\
\text { incidência do imposto de renda } \\
\text { sobre rendimentos recebidos } \\
\text { acumuladamente. 3- Assim, } \\
\text { indefiro o pedido de } \\
\text { antecipação de tutela." } \\
\begin{array}{c}\text { AG -2009.04.00.004386-5 - SC } \\
\text { - 16/02/2009 }\end{array}\end{array}$ & $\begin{array}{l}\text { "1. No caso de recebimento } \\
\text { acumulado de valores } \\
\text { decorrentes da procedência de } \\
\text { ação judicial, que determinou a } \\
\text { incorporação de vantagem à } \\
\text { remuneração dos policiais } \\
\text { civis, a interpretação literal da } \\
\text { legislação tributária implica } \\
\text { afronta aos princípios } \\
\text { constitucionais da isonomia e } \\
\text { da capacidade contributiva, } \\
\text { Porquanto a renda a ser } \\
\text { tributada deve ser aquela } \\
\text { auferida mês a mês pelo } \\
\text { contribuinte, sendo descabido } \\
\text { "puni-lo" com a retenção a } \\
\text { título de IR sobre o valor dos } \\
\text { benefícios percebidos } \\
\text { acumuladamente por mora da } \\
\text { autarquia previdenciária", } \\
\text { (grifos nossos). } \\
\text { AC - 2002.71.12.003720-9 - RS } \\
\text { 04/05/2005 }\end{array}$ \\
\hline $\begin{array}{l}\text { SOLUÇÃO DA } \\
\text { ANTINOMIA }\end{array}$ & $\begin{array}{c}\text { Prevalência da regra, } \\
\text { densifica valores }\end{array}$ & Prevalência dos princípios \\
\hline MÉTODO & $\begin{array}{c}\text { Aplicação da regra pura e } \\
\text { simplesmente }\end{array}$ & $\begin{array}{c}\text { A análise tópico-sistemática } \\
\text { das regras, princípios e valores }\end{array}$ \\
\hline FUNDAMENTO & Regra & $\begin{array}{l}\text { Hierarquização prudencial } \\
\text { entre normas }\end{array}$ \\
\hline
\end{tabular}




\begin{tabular}{|c|c|c|c|}
\hline Interpretação & $\begin{array}{c}\text { PENSAMENTO } \\
\text { CONCEITUALISTA }\end{array}$ & $\begin{array}{c}\text { PENSAMENTO } \\
\text { NORMATIVISTA }\end{array}$ & $\begin{array}{c}\text { PENSAMENTO } \\
\text { SISTEMÁTICO }\end{array}$ \\
\hline Obtração de sentido & $\begin{array}{c}\text { Compreensão } \\
\text { (sentido) da } \\
\text { incidência }\end{array}$ & $\begin{array}{c}\text { Aplicação de uma } \\
\text { compreensão } \\
\text { (sentido) }\end{array}$ \\
\hline Método Estudo & Essência do sentido & Estrutura do sentido & Sentido da estrutura \\
essência & $\begin{array}{c}\text { Descrição de uma } \\
\text { estrutura de sentido }\end{array}$ & $\begin{array}{c}\text { Construção de } \\
\text { sentido }\end{array}$ \\
\hline
\end{tabular}

\section{CONSIDERAÇÕES FINAIS}

Algumas críticas poderiam ser esboçadas contra uma teoria sistemática, dentre as quais poderíamos citar: excesso de insegurança, complexidade, risco de decisões judiciais distanciadas das leis e mesmo o excesso de constitucionalização do Direito Triubtário. A estas críticas podemos afirmar que os desejos de manter uma defesa intransigente da segurança jurídica possuem mais o espírito de nostalgia de um passado perdido, visto que um mundo dinâmico, com uma sociedade complexa e fundada no risco, não pode se permitir ao luxo de viver em um mundo inexistente. A complexidade exige novos instrumentos de análise e a melhor garantia contra a falta de controle judicial está justamente na presença de mecanismos de explicitação das decisões, de sua coerência material e consistência teórico-prática.

\section{RESUMO}

1. O problema da interpretação jurídica aparece igualmente de modo diverso em cada modo de pensar o jurídico. O pensamento normativista partirá de um modelo diverso de interpretação da norma jurídico-tributária, visto que para este o modelo de interpretação não visa apenas a extração de sentido do dispositivo normativo, mas especialmente a construção de sentido. Trata-se de um modo absolutamente revolucionário para a época em que foi formulado e para a formatação da ideia de direito.

2. O pensamento sistemático irá produzir um conjunto de novos modelos, instrumentos e agenda de trabalho, muito superior ao que existia nos momentos anteriores, implicando em uma nova forma de interpretação jurídico-tributária.

3. A interpretação tópico-sistemática caracteriza-se por hierarquizar prudencialmente princípios, regras e valores em uma nova formulação. Assim, a antinomia regras e princípios, será antes um conflito entre os fundamentos das normas (princípios em contradição) do que entre normas de estaturas diferentes. Tal postura supera o normativismo defensor puro de regras, o legalismo defensor de enunciados normativos e o decisionismo puro. 


\section{BIBLIOGRAFIA}

Da interpretação jurídico

AARNIO, A. The rational as reasonable. A treatise on legal justification. D. Reidel Publishing Company, 1987.

AARNIO, A., ALEXY, R. e PECZENICK, A. The Foundation of Legal Reasoning, Rechttheorie 12, 1981.

AARNIO, Aulius et alii . La Normatividad del Derecho. Barcelona: Gedisa, 1997.

ALCHOURRON, Carlos e BULYGIN, Eugênio. Introducción a la Metodologia de las Ciencias Jurídicas y Sociales. Buenos Aires: Editorial Astrea, 1993.

ATIENZA, Manuel y MANERO, Juan Ruiz. Las Piezas del Derecho: teoria de los enunciados jurídicos. Barcelona, Ariel, 1996.

BONAVIDES, Paulo. Curso de Direito Constitucional. 13. ed. São Paulo: Malheiros, 2003.

CARRIÓ, Genaro. Notas sobre el derecho y lenguaje. Buenos Aires: Abeledo Perrot, 1990.

DWORKIN, Ronald. Law's Empire. The Belknap Press of Havard University Press, 1986.

DWORKIN, Ronald. O Império do Direito. Tradução Jefferson Luiz Camargo. São Paulo: Martins Fontes, 1998.

DWORKIN, Ronald. Taking Rights Seriously. London: Duckworth,1984.

ECO, Umberto et alii. Interpretação e sobreinterpretação. Lisboa: Presença, 1993.

FERRAZ JR., Tércio Sampaio. Introdução ao estudo do Direito - Técnica, Decisão, Dominação. 2. ed. São Paulo: Atlas, 1994.

FREITAS, Juarez. A Interpretação Sistemática do Direito. 3. ed. São Paulo: Malheiros, 2002.

GRAU, Eros Robert. Ensaio e Discurso sobre a interpretação/aplicação do Direito. 2. ed. São Paulo: Malheiros, 2003.

HÄBERLE, Peter. Hermenêutica Constitucional - A sociedade aberta dos intérpretes da Constituição - Contribuição para a interpretação pluralista e "procedimental" da Constituição. Tradução: Gilmar Ferreira Mendes. Porto Alegre: Sergio Antônio Fabris, 1997

HART, H. L. A. O Conceito de Direito. Lisboa: Fundação Calouste Gulbenkian, 1994. KELSEN, Hans. Teoria Pura do Direito. São Paulo: Martins Fontes, 1985.

MACCORMICK, Neil. Legal Reasoning and Legal Theory. Oxford University Press, 1978.

MENDES, Gilmar Ferreira, COELHO, Inocêncio Mártires e BRANCO, Paulo Gustavo Gonet. Hermenêutica Constitucional e Direitos Fundamentais. Brasília: Brasília Jurídica, 2000.

NINO, Carlos S. Derecho, Moral y Política: una revisión de la teoria general del derecho. Barcelona: Ariel, 1994.

RAWLS, John. Uma Teoria da Justiça. Lisboa: Editorial Presença, 1993.

RAZ, Joseph. The Authority of Law. Oxford: Claredon Press, 1979.

ROSS, Alf . Sobre el Derecho y la Justicia, Buenos Aires: Eudeba, 1963.

VILANOVA, Lourival. As Estruturas Lógicas e o Sistema do Direito Positivo. São Paulo: Max Limonad, 1997. 
Da interpretação jurídico-tributária

BARROSO, Luís Roberto. Interpretação e Aplicação da Constituição, 6. ed., São Paulo: Saraiva, 2004.

BECKER, Alfredo Augusto. Teoria Geral do Direito Tributário. São Paulo: Saraiva, 1953.

BORGES, José Souto Maior. Obrigação Tributária (Uma introdução metodológica). São Paulo: Saraiva, 1984.

BUJANDA, Sainz de F. Estúdio Preliminar In GIANNINI, A.D. Instituciones de Derecho Tributario. Madri: Editorial de Derecho Financero, 1957.

CALIENDO, Paulo. Dos três modos de pensar a tributação ou repensar o raciocínio jurídico-tributário. In: ROCHA, Leonel Severo; STRECK, Lenio Luiz. (Org.). Constituição, Sistemas Sociais e Hermenêutica. Porto Alegre: Livraria do Advogado, 2005, v., p. 93-111.

CAMPOS, Antônio J. Franco. Interpretação Hermenêutica e Exegese do Direito Tributário. São Paulo: Bushatsky, 1977. CAMPOS, Antônio J. Franco Direito Tributário. São Paulo: J. Bushatsky, 1975.

CARVAlHO, A. A. Contreiras de. Doutrina e Aplicação do Direito Tributário. São Paulo/ Rio de Janeiro: Freitas Bastos.

CARVALHO, P. B. Sobre o percurso de construção de sentido: modelo de interpretação do direito tributário. In: André Ramos Tavares; Gilmar Ferreira Mendes; Ives Gandra da Silva Martins. (Org.). Lições de Direito Constitucional em Homenagem ao Jurista Celso Bastos. São Paulo: Saraiva, 2005.

CARVALHO, P. B. Homenagem a Alfredo Augusto Becker. In: Dejalma de Campos. (Org.). Tributo a Alfredo Augusto Becker. São Paulo: Academia Brasileira de Direito Tributário, 1995.

CARVALHO, P. B.; SOUSA, R. G.; CANTO, G. U. ; JARACH, D.; ATALIBA, G. Interpretação do Direito Tributário. São Paulo: Saraiva e EDUC, 1975.

CARVALHO, Paulo de Barros. Direito Tributário - Fundamentos Jurídicos da Incidência. São Paulo: Saraiva, 1998.

CARVALHO, Paulo de Barros. Teoria da Norma Tributária. 2. ed. São Paulo: Revista dos Tribunais, 1981.

DERZI, Misabel Abreu Machado. Construindo o Direito Tributário na Constituição. Belo Horizonte: Del Rey, 2004.

FREITAS, Juarez. A Interpretação Sistemática do Direito. 3. ed. São Paulo: Malheiros, 2002.

GIANNINI, A.D. Instituciones de Derecho Tributario. Madri: Editorial de Derecho Financero, 1957.

GUASTINI, Ricardo. Das Fontes às Normas. São Paulo: Quartier Latin, 2005.

MAXIMILIANO, Carlos. Hermenêutica e Aplicação do Direito. Rio de Janeiro: Forense, 2006.

MERSÁN, Carlos. Direito Tributário. São Paulo: RT, 1988.

MORSELLI, Emanuele. Corso di Scienza della Finanza Pubblica. Padova: CEDAM, 1949.

TÔRRES, Ricardo Lôbo. Normas de Interpretação e Integração do Direito Tributário. Rio de Janeiro: Forense, 1991. 